A R T I CLE

\title{
Brazilian International Development Cooperation and Public Opinion: Domestic Costs Faced by a Troubled Emerging Donor
}

\author{
Matheus Soldi Hardt 1 \\ https://orcid.org/0000-0001-9887-1055 \\ Fernando Mouron ${ }^{1}$ \\ https://orcid.org/0000-0002-3629-3082 \\ Laerte Apolinário Júnior ${ }^{2}$ \\ https://orcid.org/0000-0002-8326-4428
}

\author{
${ }^{1}$ King's College London, Brazil Institute. London, United Kingdom \\ ${ }^{2}$ Pontifícia Universidade Católica de São Paulo, Departamento de Relações \\ Internacionais, São Paulo/SP, Brazil
}

In recent decades, Brazil has established itself as an important donor to underdeveloped countries. Although the country does not see itself as a traditional donor, its IDC policy, in the context of South-South Cooperation, has increased the country's international profile as an influential actor in the IDC landscape. However, emerging states, generally classified as middle-income countries, continue to suffer from high levels of poverty, which leads to debate on whether resources used in international aid could not be better used at home. The supply of foreign aid is influenced by public opinion in democratic donor countries; generally speaking, foreign aid is unpopular relative to domestic programs. This article, by means of an experimental design, analyzes Brazilian public support for the country's IDC policy and engages with the emerging literature on Brazilian public opinion and foreign policy issues. It thus contributes to the discussion about the domestic costs of Brazil becoming an emerging donor. Our findings, based on a national survey of 2276 people, show that most respondents believe the country should reduce or eliminate foreign aid spending. Moreover, support decreases even more when participants are presented with information on how that money could have been used in the domestic realm.

Keywords: Brazilian foreign policy; foreign aid; public opinion; survey experiment.

http://doi.org/10.1590/1981-3821202000010001

For data replication, see: https://doi.org/10.7910/DVN/7MBL20

Correspondence: Laerte Apolinário Júnior. E-mail: laerte.apolinario.junior@usp.br

This publication is registered under a CC-BY Licence. 
or the first time, other global powers have begun to recognize Brazil as an influential actor in the international arena (SCHIRM, 2012). Despite its lack of military capabilities, the country has achieved unprecedented international status due to the role it plays in multilateral fora and its active participation in international cooperation initiatives (CERVO, 2010). In this regard, previous authors have analyzed how Brazil's increasing influence in international affairs can be explained by its focus on cooperation strategies, as well as its prioritization of South-South relations (CHRISTENSEN, 2013; DAUVERGNE and FARIAS, 2012; INOUE and VAZ, 2012).

Brazilian diplomats and academics generally agree with the idea that the country's engagement with international cooperation is an instrument of foreign policy (LEITE et al., 2014). The literature on Brazilian Cooperation points out that this effort was motivated by new international ambitions, which aimed to expand the country's presence in global negotiations, international regimes and multilateral organizations. Thus, among the reasons related to the provision of International Development Cooperation (IDC), the ones most commonly mentioned in the literature are the search for closer ties with developing countries (CERVO, 1994; PINO and LEITE, 2010; PUENTE, 2010; VALLER FILHO, 2007), the search for 'greater voice' in international organizations (APOLINÁRIO JÚNIOR, 2016; HARDT, MOURON, and APOLINÁRIO JÚNIOR, 2017; HIRST, 2011) the search for support for a permanent seat in the UN Security Council, an objective that became a priority for Brazilian foreign policy during the Lula administration (HIRST, LIMA and PINHEIRO, 2010), and the search for new markets for its national companies and exports (SOUZA, 2012; WARNER, 2015).

Nevertheless, most of the aforementioned studies have only analyzed the effects of Brazil's IDC policy on the country's international standing, without considering its domestic implications. Therefore, our aim in this study is to examine the domestic costs of Brazilian IDC policy as an example of how public opinion on foreign policy is sensitive to framing, given that the supply of foreign aid to recipients is influenced by public opinion in democratic donor countries. States are usually influenced by their citizens in determining the amount of foreign aid they disburse (MOSLEY, 1985). Aid budgets usually rise in parallel with 
increases in public support (STERN, 1998). Likewise, economic crises generally lead to reductions in foreign aid, because publics place a lower priority on aid during economic downturns and politicians respond with cuts (HEINRICH, KOBAYASHI and BRYANT, 2016). Some authors suggest that public support for aid affects both its quantity and effectiveness (COLLIER, 2007). For these reasons, it is important to understand public support for foreign aid. Moreover, understanding the determinants of support for foreign aid can help policy makers formulate better arguments in favor of aid and design policies more consistent with public preferences (PAXTON and KNACK, 2012).

Milner and Tingley (2013) provide an extensive review of research exploring this relationship. They argue that, in general, foreign aid is unpopular relative to domestic programs. They show that in the 2008 American National Election Study, 44\% of respondents wanted foreign aid cut, while $79 \%$ wanted funding for public schools to expand. In another cross-national survey conducted in 2012 by the Council on Foreign Relations, 59 percent of Americans indicated that they thought that the government spends too much on foreign aid (HURST, TIDWELL and HAWKINS, 2017). However, public support for aid tends to be stronger in other donor countries (PAXTON and KNACK, 2012; STERN, 1998).

Approaching from a different angle, Milner and Tingley (2013) analyze whether there are consistent cleavages on foreign aid and whether these cleavages can be theoretically explained. A strategy used in the study of preferences in other policy areas, such as trade policy, is to consider the role of ideological and material explanations. They find that there is an important influence of ideology and partisanship in many of the public opinion polls that have looked at attitudes in donor countries. Similar partisan divides are present in elite-level studies as well as in cross-national work (NOEL and THÉRIEN, 2008; PAXTON and KNACK, 2012; TINGLEY, 2010). Regarding the material factors, there is an emerging consensus that individuals in rich donor countries with greater endowments of capital, such as high skills or education, are more likely to support aid, while those with less education, and hence fewer gains from international engagement, are less supportive (MILNER and TINGLEY, 2013; PAXTON and KNACK, 2012).

In another study, Paxton and Knack (2012), through a large, multi-level, cross-national study of seventeen donor-countries, finds evidence that publics 
have consistent opinions on foreign aid activities. Their findings support predictions that attitudes toward aid are influenced by cultural and material factors such as religion, beliefs about the causes of poverty, awareness of international affairs and trust in people and institutions.

Earlier research suggests that the public have consistent attitudes about foreign aid and that these attitudes matter. The general population may constrain elites, and may reflect elite views. Milner and Tingley's (2013) findings support the view that partisan debates in the United States over the role of aid match the public's overall preferences. The act of giving aid thus seems to reflect public attitudes.

Noel and Thérien (2002) argue that attitudes to international redistribution are not a simple projection of attitudes about the domestic situation. They claim that in countries where domestic income redistribution is seen as an important priority, foreign aid is less popular. Where this is less so, there is more concern for the fate of the poor in the global South. Instead of believing that this finding reflects a lack of coherence in public opinion, they conclude that, although the commitment to redistribution is stronger at the domestic level, relationships of solidarity do not stop at national boundaries. The achievement of justice at home in fact sustains justice abroad.

In relation to cultural characteristics, Baker (2015) explores the cultural effects of public support for aid, especially in relation to race and paternalism. Contradicting the previous literature that believes that white Americans are less enthusiastic about welfare for non-white than white recipients, they find that when it comes to foreign aid, white Americans are more favorable toward aid to poor non-whites than to poor white people. They argue that this relationship is due to an underlying racial paternalism. Their research is based on experimental data in which the race of hypothetical aid recipients was randomly manipulated.

However, Milner and Tingley (2013) emphasize that neither those who see theoretical primacy in material factors nor those who emphasize cultural variables have clearly identified the role of material or cultural explanations. In this sense, they advocate the view that better causal identification of material versus cultural 
factors in driving attitudes toward aid will be best obtained from a sustained experimental agenda that includes survey experiments.

Following this trend, Hurst, Tidwell and Hawkins (2017), by means of a survey experiment, analyze whether framing effects can impact public views on foreign aid. Contrasting arguments in favor of and against foreign aid, they find that the way in which the supply of aid is presented to the public has an impact on support, especially in the case of arguments related to the cost of aid.

Although there is a consolidated literature that analyzes the relationship between public opinion and the provision of foreign aid by developed countries (BAKER, 2015; HURST, TIDWELL and HAWKINS, 2017; MILNER and TINGLEY, 2010; MOSLEY, 1985; NOEL and THÉRIEN, 2002; PAXTON and KNACK, 2012; STERN, 1998), work is in the pipeline that evaluates the domestic costs of the foreign aid provided by developing countries, generally referred to as South-South Cooperation for Development, and the international assistance provided specifically by Brazil.

Considering the role that public opinion plays in Brazilian foreign policy formulation (LOPES, 2011), this article first analyzes support for the country's IDC policy. Traditional public opinion surveys have provided some information relevant to this issue and have assumed that Brazilians who voice support for helping other developing countries automatically agree with the country's foreign aid practices (AZEVEDO, SANTOS JÚNIOR and RIBEIRO, 2009). However, given methodological considerations, we argue that these conclusions are misleading.

Secondly, taking into account the fact that foreign policy issues can be used to gain advantage in the domestic realm (ALDRICH et al., 2006), this article also examines how Brazilians react to the major criticisms consistently used by the opposition to undermine the former administration's IDC policy. Briefly, these critiques have focused on 01 . the large amounts directed to foreign aid and 02 . how that funding could have been used domestically. To this end, we conducted an online survey experiment on a national representative sample composed of 2276 people. The experimental design aimed to determine whether the way a particular IDC policy, namely, the United Nations Stabilization Mission in Haiti ${ }^{1}$

\footnotetext{
${ }^{1}$ MINUSTAH was a peace mission under Brazilian leadership established by the United Nations Security Council (UNSC) on 30 April 2004. It aimed to restore security and institutional normality in Haiti following the repeated episodes of political turmoil and violence that led to the exile of President Jean-Bertrand Aristide (UNITED NATIONS, 2016).
} 
(MINUSTAH), was framed would change respondents' perceptions of whether Brazil ought to increase, maintain, reduce or eliminate investment in foreign aid.

Our findings show that at least 70 percent of Brazilians, based on our sample, believe the country should reduce or completely eliminate spending on foreign aid. Contrary to our expectations, support for foreign aid increased by 8.76 percent when participants were informed of Brazil's spending on MINUSTAH from 2004-2014. However, when the same information was contrasted with how this money could have been used domestically, support for foreign aid decreased, and 78.97 percent of respondents declared that Brazil should reduce or completely eliminate funding for foreign aid.

This paper is structured as follows. In the next section we contextualize our research, explain how Brazilian cooperative initiatives have evolved during the last decade and assess how previous public opinion surveys have addressed this issue. Next, we present a theoretical discussion on how public opinion influences foreign policy formulation and how foreign policy issues can be used to gain advantages in the domestic realm, together with our hypotheses. We then describe our survey experiment and present our results. Finally, we discuss our findings and present several conclusions.

\section{A new path in Brazilian foreign policy}

The influence of emerging countries on the architecture of International Cooperation for Development has brought profound changes to the cooperation processes. The flows of IDC resources to finance development activities have increased significantly in terms of volume and the number of beneficiaries in the last decade (BESHARATI and ESTEVES, 2015; MAWDSLEY, 2012; QUADIR, 2013). At the same time, emerging states, generally classified as middle-income countries, still evince high levels of poverty, which gives rise to a debate on whether resources used in international aid could not have been better allocated in the domestic environment with development programs that would decrease social inequality. 
Brazilian IDC initiatives, conducted in the context of South-South Cooperation (SSC) ${ }^{2}$, became increasingly prominent as part of former president Luiz Inácio Lula da Silva's (2003-2010) foreign policy (RENZIO and SEIFERT, 2014). Although not an innovation of the Brazilian Workers' Party (PT), under the Lula and Dilma administrations, South-South relations climbed to the top of Brazilian foreign policy priorities, with a significant increase in the number of cooperation agreements signed with developing countries (MENDONÇA JÚNIOR and FARIA, 2015). Simultaneously, over the last decade Brazil has shifted in status from a receiver to a donor of foreign aid $^{3}$, while its integration strategy has been reinforced by the promotion of alliances and agreements with southern partners (APOLINÁRIO JÚNIOR, 2016; OLIVEIRA and ONUKI, 2012; PINHEIRO and GAIO, 2014; PUENTE, 2010; VALENÇA and CARVALHO, 2014) .

During this period, Brazilian foreign aid $^{4}$ has ranged from technical assistance and debt relief for poorer countries, to a commitment to help countries affected by natural disasters or internal conflicts by means of international humanitarian assistance. It is notable that the Brazilian government neither sees itself as a donor, nor refers to its IDC policy as foreign aid. In this sense, the country has tried to distance itself from the concepts and conventional practices of foreign aid used by developed countries. Brazil's official discourse states that IDC policy should be based on ideals of solidarity and exchange of common experiences and have no links with commercial interests or foreign direct investment. As an example of this interpretation, Brazil has rejected the Development Assistance Committee of the Organization for Economic Cooperation and Development (OECD/DAC) terminology5, instead using the United

\footnotetext{
2There is no consensus on the definition of SSC but it is generally used to designate a wide range of phenomena regarding relations between developing countries. However, the term can also refer to specific actions taken by a government to promote economic development in underdeveloped countries, such as technical and financial assistance (LEITE, 2012).

${ }^{3}$ According to a study conducted by Le Monde Diplomatique Brasil in 2011, the Brazilian government provided more international aid than it received from other countries and multilateral agencies between 2005 and 2009 (ROSSI, 2011). However, Brazil continues to be a recipient of foreign aid at the international level, which is one of the reasons why the country seeks to distance itself from the official DAC/OECD terminology (MILANI, 2018).

4This study uses this narrower conception of South-South Cooperation for Development, using the terms foreign aid and IDC to refer to the same phenomenon.

${ }^{5}$ See the glossary of OECD statistical terms (OECD, 2019).
} 
Nations Conference on Trade and Development's (UNCTAD's) definition of cooperation (MILANI and CARVALHO, 2013) ${ }^{6}$.

However, this paper uses the foreign aid concept in its research design, defining this activity as "voluntary transfer of public resources from one government to another, with the aim of promoting development in the recipient country" (LANCASTER, 2007, p. 09).

The reasons are both theoretical and practical. As for the theoretical question, this research dialogues more directly with the literature on the relationship between public opinion and foreign aid. Thus, this research analyzes to what extent the determinants of public support for the supply of foreign aid are verified in developing countries in relation to the provision of the South-South Cooperation for Development. Regarding the practical reasons, a pre-test of the experiment was run in a small sample composed of International Relations students from the University of São Paulo. In this pilot test, we used the term 'International Development Cooperation'.

However, the students had some difficulty in associating the term with the phenomenon we intended to analyze. It is worth remembering that there is no consensus on the concept of cooperation and it is generally used to designate a wide range of phenomena associated with relations between countries. In this sense, the expression refers to policies of exchange, dialog and rapprochement between countries, both bi- and multilaterally. Nonetheless, the term can be used in a more specific sense to designate the actions carried out by a government to promote economic development in another country. In this sense, the term resembles the traditional concept of foreign aid. Thus, it was found that students had a better sense of the phenomenon when we used the term 'foreign aid' rather than 'development cooperation'.

Under this umbrella, Brazil's peacekeeping operations can be regarded as part of its international development cooperation policy. Hence, Brazilian

\footnotetext{
'Instead of employing the terms 'donor' and 'receiver', Brazil refers to countries involved in development cooperation as 'partners'. The idea behind this movement is that South-South relationships constitute a more equal collaboration, as both countries are trying to develop themselves, and are therefore not interested in taking advantage of one another.
} 
participation in MINUSTAH cannot be understood solely as a military operation in Haiti. In addition to troops, other personnel such as engineers, doctors and nurses performed important social tasks in the country, including implementing policies for Haiti's socioeconomic development. In this regard, the Brazilian government supported rapid-impact programs in the social arena, including building schools, hospitals, roads and public buildings, in addition to other projects to reduce violence in communities. Furthermore, the Brazilian military promoted sociocultural activities to support the neediest communities, such as outdoor film screenings, distribution of clean water and school supplies, and lectures on personal hygiene and disease prevention. In summary, MINUSTAH can be considered one of the largest Brazilian efforts in terms of foreign aid (IPEA/ABC, 2016, pp. 157-158).

As Brazil increased its foreign aid initiatives, scholars began to assess public opinion on this issue. Between 2006 and 2008, the Observatory of the Metropolises, in partnership with other national and international organizations, conducted a comparative survey to understand the exercise of citizenship in seven countries (Brazil, Canada, France, Sweden, Spain, Portugal and the United States). Respondents were asked about the importance of 'helping people around the world who live in precarious situations', and, taking those answers as a reference, the authors created an indicator that ranged from zero to seven (zero = not at all important; seven = very important). Despite living in the least developed country in the sample, Brazilians, with an average of 6.23, most enthusiastically supported helping people in precarious situations (AZEVEDO et al., 2009, p. 353). This finding prompted some scholars to conclude that there is strong internal support for what they referred to as a 'humanistic' and 'solidarity-based' foreign policy ${ }^{7}$ (FARIA and PARADIS, 2013).

Notably, during the same years, significant domestic debate began to focus on the question of whether Brazil should play an active role as a foreign donor. These policies and projects were justified under the Lula and Dilma administrations by the notion that Southern countries shared common values and

\footnotetext{
${ }^{7}$ The principle of solidarity was stressed by President Lula in his inaugural speech, when he emphasized the main guidelines of his foreign policy, defending the 'democratization of international relations without hegemony of any kind' and a diplomacy oriented by a 'humanist perspective' (PRESIDÊNCIA DA REPÚBLICA, 2003).
} 
interests as well as by a sense of duty and moral obligation to assist other developing nations. However, despite the existence of this 'solidarity' discourse, critical voices were raised against the country's foreign aid policy during the same period. These critics, together with some methodological considerations, made us wonder whether the conclusions about Brazilians supporting a solidarity foreign policy were correct. Furthermore, the local understanding of foreign policy matters is a complex issue (ALMEIDA et al., 2017; ALMEIDA, FERNANDES and GUIMARÃES, 2019; ALMEIDA, ONUKI and CARNEIRO, 2014; GUIMARÃES, FERNANDES and MALDONADO, 2019; ONUKI, ALMEIDA and CARNEIRO, 2016; ONUKI et al., 2016).

This literature has addressed issues such as the desirability of regional leadership (ALMEIDA, ONUKI and CARNEIRO, 2014); Brazil playing an active role in scenarios of regional conflict and financial assistance to less developed countries (ONUKI et al., 2016); public perceptions regarding the emerging Chinese-American rivalry (URDINEZ and RODRIGUES, 2017); regional leadership in material and institutional terms regarding regional issues such as economic integration, regime change and regional conflict (GUIMARÃES, FERNANDES and MALDONADO, 2019); and the structure of the Brazilian public's attitudes towards foreign policy issues in general (ALMEIDA, FERNANDES and GUIMARÃES, 2019).

Almeida, Piquet and Onuki (2014), in the 2010 survey report 'Brasil, as Américas e o Mundo', show that the support for Brazil's regional leadership was backed by $49 \%$ of respondents (ALMEIDA, ONUKI and CARNEIRO, 2014). However, in the updated survey report, support for leadership dropped to $27 \%$ (ALMEIDA et al., 2017). Onuki, Mouron and Urdinez (2016) found that most Brazilians reject the idea of Brazil playing an active role in scenarios of regional conflict and financial assistance to less developed countries. Guimarães, Fernandes and Maldonado (2019) found that when the Brazilian public is confronted with scenarios involving costly decisions, especially in terms of regime change and regional conflicts scenarios, the public tends to reject regional leadership, choosing instead options in which Brazil does not act as a leader. Almeida, Fernandes and Guimarães (2019) show that the Brazilian public opinion is more structured and stable than previously thought. Adding to the literature at a regional level, 
Onuki, Mouron and Urdinez (2016) found that the Argentinian public are sensitive to framing effects, especially concerning Brazilian leadership.

In general, these results indicate that the Brazilian public has a skeptical view of the concept of Brazil playing a more active role in international affairs, especially when material costs are involved, and it is more structured and stable than previously thought.

Therefore, dialoging with the literature on Brazilian public opinion and foreign policy issues, we ask whether Brazilians are truly so supportive of the country's foreign aid policy, and how critical discourses impact public opinion on this issue.

\section{Brazilian public opinion revisited}

\section{Are Brazilians in favor of helping poor countries?}

The public, through approval or disapproval, influences the actions of policy-makers (BURSTEIN, 2003). Members of the Executive and Legislative branches are aware that they are accountable, and therefore try to respond to - or anticipate - public opinion as a way to remain in power and/or win elections (HOLSTI, 1992; MILNER and TINGLEY 2010, 2013). With respect to foreign aid initiatives, previous studies in developed countries have shown that taxpayer opinion helps determine the quantity and quality of the aid disbursed (MOSLEY, 1985). In other words, countries with higher levels of public support for aid tend to spend more on helping developing nations (STERN, 1998).

Azevedo et al. (2009) concluded that Brazilians agreed with the country following a solidarity-based foreign aid policy. However, this study's optimistic conclusions are not consistent with the results of others conducted worldwide. For example, a survey carried out in 2014 in 28 European countries showed that at least 51 percent of respondents did not think that addressing poverty in other countries should be one of their governments' priorities ${ }^{8}$. Additionally, a survey conducted in the United States by the Pew Research Center demonstrated that American public opinion on this issue was divided, with 48 percent of those

\footnotetext{
${ }^{8}$ See the Eurobarometer survey: The European Year for Development - Citizens' views on development, cooperation and aid (EUROPEAN COMMISSION, 2019). Available at <http://ec.europa.eu/public_opinion/archives/eb_special_439_420_en.htm>.
} 
interviewed believing that foreign aid should be cut and 49 percent thinking that it should be increased or at least maintained ${ }^{9}$. Given these contrasting results, is there some feature that distinguishes the Brazilian case from others?

It is possible that Brazil is an exception. However, due to methodological considerations and the particular characteristics of foreign aid, we argue that previous evidence is not a reliable indicator of the Brazilian public's perceptions of the country's IDC policy. Briefly, the main deficiency of the aforementioned study was its lack of methodological precision. What was measured was not Brazilians' support for the country's foreign spending per se but rather participants' endorsement of abstract ideas, such as 'the importance of helping less developed countries'. People's answers to questions that include moral considerations are always influenced by what extensive literature has referred to as 'social desirability bias'. Respondents tend to hide their real preferences if they believe that their beliefs are not compatible with what society expects (KRUMPAL, 2013), behavior that is reinforced when surveys are conducted face-to-face (HOLBROOK, GREEN and KROSNICK, 2003) and use self-reported values (FISHER and KATZ, 2000), as was the case in the aforementioned study.

Therefore, we expect that if participants are asked to give an opinion about Brazilian foreign aid itself, instead of a personal statement on whether they agree with helping others, support for spending money on foreign aid will be lower (H1).

\section{A tool used in the domestic debate}

It is widely understood that domestic and foreign policy are intrinsically related. Since Putnam (1988) showed that national leaders think about both national and international outcomes while ratifying an international agreement, many studies have sought to analyze the interaction between the two spheres. In general, both incumbents and opposition candidates appear to spend time and effort campaigning on foreign and defense policies only when they believe this can bring them electoral benefits (ALDRICH, SULLIVAN and BORGIDA, 1989). For

\footnotetext{
${ }^{9}$ For more information, see Pew Research Center (2013). Available at <http://www.people-
} press.org/2013/02/22/as-sequester-deadline-looms-little-support-for-cutting-most-programs/>. 
ruling parties, as Snyder et al. (2009) show with respect to the US-led invasion of Iraq, foreign policy issues can be used to emphasize looming foreign threats, overshadowing domestic class divisions and attracting votes to incumbent candidates (SNYDER, SHAPIRO and BLOCH-ELKON, 2009). For the opposition ${ }^{10}$, foreign policy mistakes have been used to criticize the current administration (CAMPBELL, 2004) or take advantage of the fact that public opinion is opposed to ongoing foreign policy processes (KRIESI, 2007).

Considering the various ways in which foreign policy issues can be used to gain advantage in the domestic realm, we ask whether Brazilian perceptions of foreign aid are sensitive to framing effects. Succinctly, framing effects theory assumes that public opinion can change according to where the public debate is directed (IYENGAR, PETERS and KINDER, 1982; SCHEUFELE and TEWKSBURY, 2007), while "small changes in the presentation of an event or topic can have large effects on the perception that the public has regarding these issues" (CHONG and DRUCKMAN, 2007, p. 104). Taking this theoretical framework into account, we test how Brazilians react to the two main arguments against the country's foreign aid policy.

On the one hand, since the beginning of the Workers' Party (PT) administrations, the prevailing discourse among opposition legislators has been that too much money has been spent on helping less-developed countries. For example, in 2004, deputy Antonio Carlos Mendes Thame, from the opposition Brazilian Social Democracy Party (PSDB), presented Bill 4128/2004, which required the executive branch to obtain specific and express permission from Congress to relieve the debts of other countries, a proposal that generated intense debate within the legislative arena. These discussions focused on controversial aspects of financial cooperation initiatives for the relief of some countries' debts, especially African ones. Also in 2004, the executive branch submitted Bill $205 / 2004$, which asked for permission to send troops to Haiti. Voting on this proposal again divided the legislators, with 118 votes against, 266 in favor, and one abstention. Those in favor of the bill mainly included the governing coalition

\footnotetext{
${ }^{10}$ Headed by the Brazilian Social Democracy Party (PSDB) and the Democrats (DEM), former Liberal Front Party (PFL).
} 
led by the Workers Party, while those opposed included the opposition base, composed of the Liberal Front Party (PFL) ${ }^{11}$ and the PSDB (FELIU and MIRANDA, 2011). Essentially, the argument used by the latter was that the bill required the country to spend too much on foreign aid. If this discourse had any effect, we expect that when given real information about how much Brazil spends on a particular foreign aid initiative, public support for this type of policy will tend to decrease (H2).

On the other hand, as the current economic crisis began to take shape, the question of whether Brazil should be an active emerging donor also began to appear in presidential debates. In general, opposition candidates used the issue to attack the incumbent candidates, claiming that taxpayer money was being wasted on other countries instead of being used to improve the living conditions of Brazilian citizens. According to this point of view, the problem was not just wasteful spending of public funds but also the fact that this money should be devoted to solving the problems of a local population that, since the beginning of the recent recession, had experienced serious hardship. For example, in the 2014 presidential debates, right-wing opposition politicians such as Pastor Everaldo from the Christian Social Party (PSC) and Levy Fidelix from the Brazilian Labour Renewal Party (PRTB) continually accused the federal government of spending money on foreign aid that should be spent domestically. During the debates, it was common to hear comments from those candidates such as the following: "Your government favors the Cuban dictatorship that does not respect human rights. It is fair to do it with the money, the sweat and the blood of the Brazilian workers?" and "In my government, the money of the Brazilian worker will stay in Brazil"(JORNAL do BRASIL, 2014; REDE GLOBO, 2014)12. More recently, it became common to hear right wing politicians criticizing the foreign aid initiatives that had gained prominence in the PT government, especially those related to financial

\footnotetext{
11The party changed its name to Democrats (DEM) in 2007.

${ }^{12}$ Some Brazilian presidential debates are available at Jornal do Brasil (2014) and Rede Globo (2014):<http://www.jb.com.br/eleicoes-2014/noticias/2014/08/26/candidatos-apresidente-da-republica-participam-de-primeiro-debate-na-tv/> and <http://g1.globo.com/politica/eleicoes/2014/noticia/2014/10/leia-e-veja-integra-do-debate-naglobo.html>.
} 
cooperation. During the 2018 elections, candidate Jair Bolsonaro constantly attacked the loans that were made by the Brazilian National Bank of Development (BNDES) to some countries ${ }^{13}$ : "Venezuelans die of hunger because of the tyranny of a government that goes hand in hand with the Cuban dictatorship. Via BNDES and other sources of its money, Brazil is one of the biggest sponsors of the socialism that massacres millions around the world. This is going to change! With us, the focus is Brazil!" (REDE GLOBO, 2018). Given this argument, we expect that Brazilian support for cooperation initiatives will diminish when the participants are given information on how money currently used for foreign aid could be otherwise applied to domestic social policies (H3).

\section{Analyzing public opinion in detail}

Finally, previous studies that addressed the question of Brazilian support for foreign aid dismissed the fact that support for foreign aid is not homogeneous but rather influenced by political and socioeconomic variables. From a political perspective, people with a leftist political orientation (BECHTEL, HAINMUELLER and MARGALIT, 2014; LUMSDAINE, 1993; PAXTON and KNACK, 2012; TINGLEY, 2010) who are more satisfied with their government (CHONG and GRADSTEIN, 2008) and more interested in politics (PAXTON and KNACK, 2012) have been shown to be more supportive of foreign aid policies. Similarly, from a socioeconomic perspective, richer ( BECHTEL, HAINMUELLER and MARGALIT, 2014; CHONG and GRADSTEIN, 2008; PAXTON and KNACK, 2012), more educated (BECHTEL, HAINMUELLER and MARGALIT, 2014) and younger (PAXTON and KNACK, 2012) respondents have appeared to support foreign aid initiatives more. Taking these studies into account, we analyze whether these socioeconomic and political variables affect Brazilians' perceptions of foreign aid.

\section{Methodology}

Our data come from an online survey experiment conducted between July 28 and August 10, 2016, using a Brazilian national representative sample. To

\footnotetext{
13It is worth noting that the BNDES does not directly finance projects abroad. What the Bank finances is the export of Brazilian engineering goods and services (BNDES, 2018).
} 
guarantee the sample's representativeness, with the help of the company Netquest $^{14}$, we invited 2276 people to answer a 07 -minute survey based on three criteria: sex, class and region ${ }^{15}$ (Annexes - item 01). Moreover, to avoid any 'device effect' (CALLEGARO, 2010) and to guarantee that our results were comparable, respondents were blocked if they tried to complete the survey with a device other than a personal computer.

After answering five socioeconomic and political questions, the participants were randomly assigned to a control group or one of two treatment groups (Annexes - item 02). Those assigned to the first treatment group received information about how much money Brazil spent on MINUSTAH between 2004 and 201416 (Annexes- item 03). Those assigned to the other treatment group were provided with the same figures, but which were presented in comparison with how that money could have been spent domestically on the construction of hospitals ${ }^{17}$ (Annexes- item 04).

Next, all respondents were asked how they thought Brazil should modify its foreign aid policy: 01. increase foreign aid, 02. maintain current levels, 03. reduce it, or 04. completely eliminate spending on it (Annexes - item 05). Because the dependent variable had four categories, we transformed it into a dichotomous variable. In this regard, given that Brazil's growth rate has contracted over the last five years ${ }^{18}$, we considered the preference to maintain the current foreign aid policy to indicate a positive attitude toward the program. Therefore, we grouped the 'Completely eliminate' with the 'Reduce' answers and the 'Maintain' with the 'Increase' answers. The aim of this procedure was to differentiate between

\footnotetext{
${ }^{14}$ The company constructs a closed panel available by invitation and through multiple sources, a strategy that avoids fake respondents and guarantees equal representativeness in the sample. For more information, see <http://www.panelwithiso.com/>.

${ }^{15}$ To ensure that the sample was representative of Brazilian society, we used as a reference the results of the 2010 Census carried out by the 'Instituto Brasileiro de Geografía e Estatística' (IBGE).

16Information required by the 'Lei de Acesso a Informação'.

${ }^{17} \mathrm{We}$ used as a reference the cost of the construction of an 8,500-square-meter hospital with all the necessary facilities and equipment to serve a population of 40,000.

${ }^{18}$ According to the World Bank, between 2011 and 2015, the Brazilian GDP fell from US\$ 2.6 trillion to US\$ 1.8 trillion. For more information, see WORLD BANK, 2018. Available at $<$ http://data.worldbank.org/indicator/NY.GDP.MKTP.CD?end=2015\&locations=BR\&start=2010\& view $=$ chart $>$.
} 
negative and positive perceptions of Brazilian foreign aid policy as well as to facilitate interpretation ${ }^{19}$.

Additionally, before and after the treatment questions, we included a series of questions to control for political variables. The questions prior to the treatments requested information about 01. Brazilian relevance in the international arena, 02. how Brazil is perceived internationally and 03. the frequency with which the respondents informed themselves about international issues. The questions that followed the treatments examined participants' 04 . party identification and 05. political ideology (Annexes - item 06). We also included classic socioeconomic questions regarding sex, age, class ${ }^{20}$ and region of residence.

Finally, to capture the average treatment effect, we carried out a cross-tab analysis. To analyze how political and socioeconomic variables affected public opinion on foreign aid, we ran logistic regression models with and without control variables.

\section{Results}

First, it is important to understand Brazilians' perceptions of foreign aid without taking any framing effect into consideration ${ }^{21}$. The results from the control group show that Brazilians predominantly want to reduce (51.4 percent) or eliminate (19 percent) spending on foreign aid, in contrast to 23.8 percent who prefer to maintain current spending levels, and 5.8 percent who support an increased budget. Therefore, independent of stimulation with information on how much Brazil has spent on foreign aid during the last decade, our results show that Brazilians' perceptions of this policy are not as positive as assumed by previous research.

In addition, prior to considering treatment effects, we ran a logistic model for the control group to analyze how various socioeconomic and political variables

\footnotetext{
${ }^{19}$ Although we could have used an ordered logistic model to analyze these four categories, this strategy could have resulted in the loss of important information. Thus, we decided to group the categories into pairs to compare positive versus negative perceptions.

${ }^{20}$ Instead of asking respondents their income, we used several questions and divided our sample into classes, a strategy adopted by IBGE. This measure guarantees compliance with ISO norms.

21For more information on descriptive statistics see Table 03 - Annexes.
} 
influence Brazilian public opinion on foreign aid (Table 01). First, holding other variables constant, our results suggest that younger people are more inclined to support foreign aid. Second, again holding other variables constant, compared to residents of the Southern region, those living in the Northeast, Southeast and Midwest are more inclined to support foreign aid.

Table 01. Foreign aid support without treatment effects

\begin{tabular}{|c|c|}
\hline Foreign aid perception & Logit \\
\hline \multirow[t]{2}{*}{ Sex } & -0.119 \\
\hline & $(0.190)$ \\
\hline \multirow[t]{2}{*}{ Age } & $-0.0361 * * *$ \\
\hline & $(0.00843)$ \\
\hline \multirow[t]{2}{*}{ Social class } & -0.0456 \\
\hline & $(0.0897)$ \\
\hline \multirow[t]{2}{*}{ Brazil's relevance } & 0.0454 \\
\hline & $(0.132)$ \\
\hline \multirow[t]{2}{*}{ Brazil's image } & $0.385^{* * *}$ \\
\hline & $(0.0936)$ \\
\hline \multirow[t]{2}{*}{ Information } & 0.0446 \\
\hline & $(0.0719)$ \\
\hline \multirow[t]{2}{*}{ Employed } & -0.302 \\
\hline & $(0.192)$ \\
\hline \multirow[t]{2}{*}{ Education } & 0.183 \\
\hline & $(0.119)$ \\
\hline \multirow[t]{2}{*}{ PT } & 0.334 \\
\hline & $(0.210)$ \\
\hline \multirow[t]{2}{*}{ PSDB } & 0.0193 \\
\hline & $(0.227)$ \\
\hline \multirow[t]{2}{*}{ Ideology } & -0.159 \\
\hline & $(0.126)$ \\
\hline \multirow[t]{2}{*}{ North } & 0.602 \\
\hline & $(0.429)$ \\
\hline \multirow[t]{2}{*}{ Northeast } & $1.071^{* *}$ \\
\hline & $(0.331)$ \\
\hline \multirow[t]{2}{*}{ Southeast } & $0.944^{* *}$ \\
\hline & $(0.324)$ \\
\hline \multirow[t]{2}{*}{ Midwest } & $1.109^{* *}$ \\
\hline & $(0.415)$ \\
\hline \multirow[t]{2}{*}{ _cons } & -1.886 \\
\hline & -1.022 \\
\hline $\mathrm{N}$ & 702 \\
\hline
\end{tabular}

Source: Elaborated by the author's.

Note: Standard errors are given in parentheses; ${ }^{*}$ indicates $\mathrm{p}<0.05,{ }^{* *} \mathrm{p}<0.01$, and ${ }^{* * *} \mathrm{p}<0.001$. 
Regarding the effects of framing, the results of the cross-tab analysis showed that the treatment groups, control group and dependent variable are associated (Table 04 - Annexes), and the results are statistically significant22. However, it is important to note that the direction of the effect differed depending on the type of information with which the respondent was stimulated. If the framing was in absolute terms, the effect relative to the control group was positive. In this situation, the respondent was more likely to answer that he/she preferred to 'Maintain' or 'Increase' the policy. In contrast, when the respondent was given the 'trade-off' information, the effect became negative, and the person was more likely to answer that the country should 'Reduce' or 'Eliminate' foreign aid. Figure 01 illustrates the effects of framing on Brazilian public opinion on foreign aid. As a robustness check, we ran logistic models including the control variables (Table 02).

Figure 01. Difference between control and treatment groups

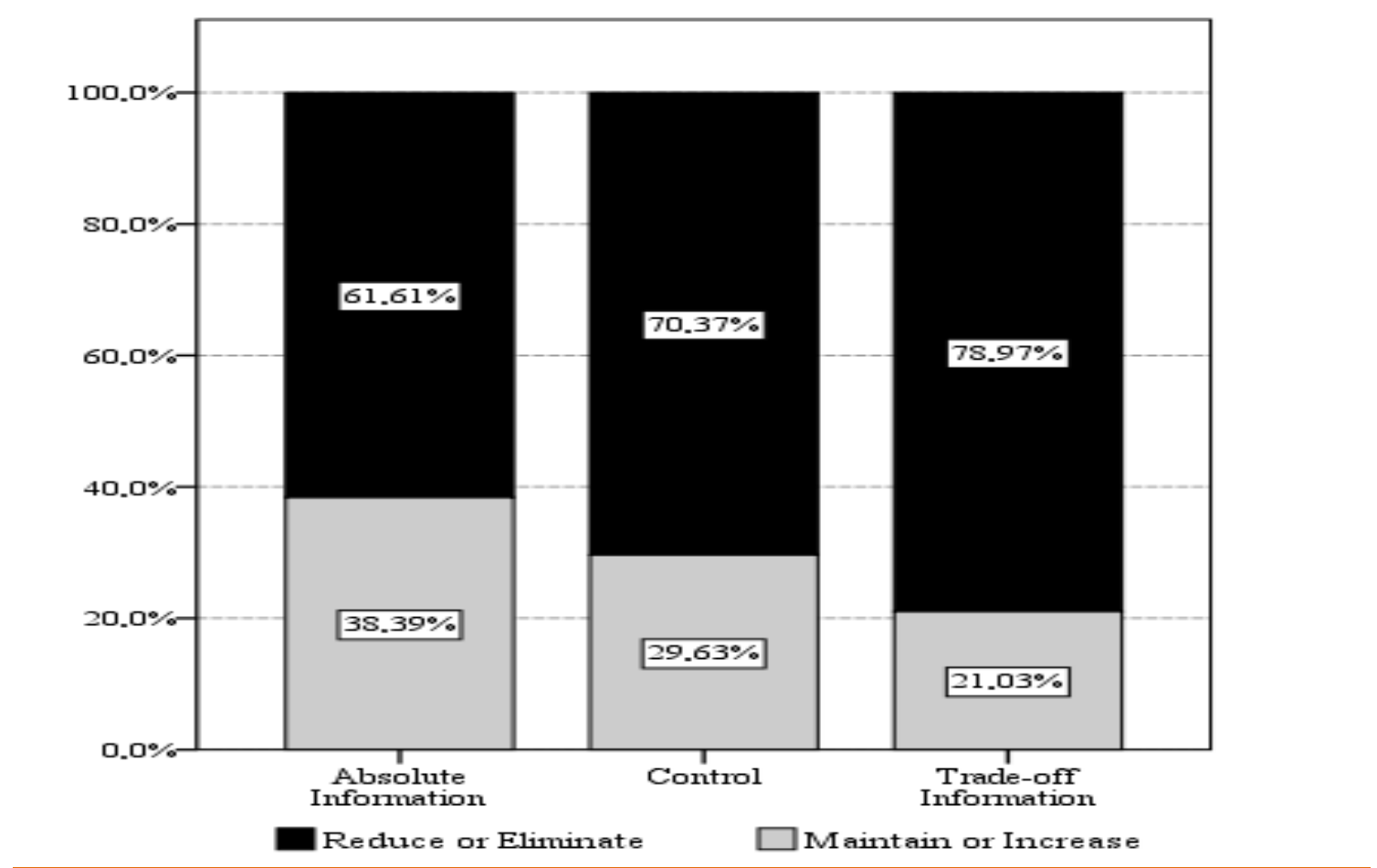

Source: Elaborated by the author's.

22The cross-tabulation analysis was made comparing the four groups and shows a difference between the behavior of participants depending in each group there were assigned. These differences of behavior were statistically tested by a chi-square test of the cross-tabulation (Table 05 - Annexes), which indicates that there is enough evidence to suggest that these differences are statically significant. 
Table 02. Framing effects with control variables

\begin{tabular}{|c|c|c|c|c|c|}
\hline & (1) & (2) & (3) & (4) & (5) \\
\hline & logit & logit & logit & logit & logit \\
\hline \multirow[t]{2}{*}{ Trade-off treatment } & $-0.458^{* * *}$ & & $-0.487^{* * *}$ & & $-0.485^{* * *}$ \\
\hline & $(0.122)$ & & $(0.127)$ & & $(0.127)$ \\
\hline \multirow[t]{2}{*}{ Absolute treatment } & & $0.392^{* * *}$ & & $0.451^{* * *}$ & $0.452^{* * *}$ \\
\hline & & $(0.110)$ & & $(0.116)$ & $(0.116)$ \\
\hline \multirow[t]{2}{*}{ Sex } & & & 0.0311 & 0.0790 & 0.0721 \\
\hline & & & $(0.138)$ & $(0.124)$ & $(0.105)$ \\
\hline \multirow[t]{2}{*}{ Age } & & & $-0.0278^{* * *}$ & $-0.0316^{* * *}$ & $-0.0282^{* * *}$ \\
\hline & & & $(0.00604)$ & $(0.00544)$ & $(0.00462)$ \\
\hline \multirow[t]{2}{*}{ Social class } & & & -0.0461 & 0.0600 & 0.0333 \\
\hline & & & $(0.0646)$ & $(0.0561)$ & $(0.0482)$ \\
\hline \multirow[t]{2}{*}{ Brazil's relevance } & & & $0.259^{* *}$ & $0.216^{*}$ & $0.286^{* * *}$ \\
\hline & & & $(0.0969)$ & $(0.0856)$ & $(0.0738)$ \\
\hline \multirow[t]{2}{*}{ Brazil's image } & & & $0.426^{* * *}$ & $0.397^{* * *}$ & $0.421^{* * *}$ \\
\hline & & & $(0.0689)$ & $(0.0627)$ & $(0.0534)$ \\
\hline \multirow{2}{*}{ Information } & & & 0.0230 & 0.0113 & 0.00588 \\
\hline & & & $(0.0525)$ & $(0.0475)$ & $(0.0404)$ \\
\hline \multirow[t]{2}{*}{ Employed } & & & -0.183 & -0.167 & -0.136 \\
\hline & & & $(0.140)$ & $(0.126)$ & $(0.107)$ \\
\hline \multirow[t]{2}{*}{ Education } & & & 0.0971 & 0.140 & 0.103 \\
\hline & & & $(0.0815)$ & $(0.0746)$ & $(0.0620)$ \\
\hline \multirow[t]{2}{*}{ PT } & & & 0.247 & $0.421^{* *}$ & $0.334^{* *}$ \\
\hline & & & (0.151) & (0.141) & $(0.118)$ \\
\hline \multirow[t]{2}{*}{ PSDB } & & & 0.0730 & 0.0324 & 0.0586 \\
\hline & & & $(0.166)$ & $(0.144)$ & $(0.125)$ \\
\hline \multirow[t]{2}{*}{ Ideology } & & & $-0.246^{* *}$ & -0.0954 & $-0.167^{*}$ \\
\hline & & & $(0.0921)$ & $(0.0829)$ & $(0.0706)$ \\
\hline \multirow[t]{2}{*}{ North } & & & $0.623^{*}$ & 0.418 & $0.459^{*}$ \\
\hline & & & $(0.300)$ & $(0.242)$ & $(0.209)$ \\
\hline \multirow[t]{2}{*}{ Northeast } & & & $0.901^{* * *}$ & $0.470^{*}$ & $0.538^{* *}$ \\
\hline & & & (0.237) & (0.194) & $(0.168)$ \\
\hline \multirow[t]{2}{*}{ Southeast } & & & $0.662^{* *}$ & 0.330 & $0.328^{*}$ \\
\hline & & & $(0.232)$ & $(0.185)$ & $(0.161)$ \\
\hline \multirow[t]{2}{*}{ Midwest } & & & $0.769^{*}$ & $0.719^{* *}$ & $0.643^{* *}$ \\
\hline & & & $(0.301)$ & $(0.243)$ & $(0.211)$ \\
\hline \multirow[t]{2}{*}{ _Constant } & $-0.865^{* * *}$ & $-0.865^{* * *}$ & $-2.294^{* *}$ & $-2.711^{* * *}$ & $-2.689^{* * *}$ \\
\hline & $(0.0827)$ & $(0.0827)$ & $(0.730)$ & $(0.642)$ & $(0.548)$ \\
\hline $\mathrm{N}$ & 1458 & 1520 & 1458 & 1520 & 2276 \\
\hline
\end{tabular}

Source: Elaborated by the author's.

Note: Standard errors are given in parentheses; * indicates $p<0.05$, ${ }^{* *} p<0.01$, and ${ }^{* * *} p<0.001$

These results confirmed the cross-tab findings (Table 04 - Annexes) and provided new information. The results of models 03 and 04 indicated that the act of assigning a participant to a treatment or the control group affected the person's 
perceptions on this issue, even when controlling for socioeconomic and political variables.

Additionally, the variables that were statistically significant in explaining public support for foreign aid, when including treatments effects, are as follows: 01. the respondent's perceptions of Brazil's relevance, 02. the respondent's perceptions of Brazil's image abroad, 03. the respondent's age, 04. all other regions besides the South, 05. whether the respondent voted for the Workers' Party, and 06. the respondent's ideology 23 .

\section{Discussion}

Contrary to previous studies (AZEVEDO, SANTOS JÚNIOR and RIBEIRO, 2009), our findings suggest that Brazilians are reluctant to continue paying the costs of an active foreign aid policy. As stated in our theoretical discussion, methodological discrepancies in how questions were asked in previous studies can explain the differences between our results and those of earlier studies. Compared to the citizens of developed countries, Brazilians have declared themselves to be more supportive of helping others, which makes sense given that historically they have been on the receiving end of foreign aid. Nevertheless, when carefully asked what Brazil's foreign aid policy should be, the respondents mostly answered that spending on other countries should be reduced or even completely eliminated. This finding probably results from a more appropriate way of measuring Brazilians' support for their country's foreign aid policy, as well as the current political and economic situation. Brazilians can individually empathize with others who suffer; however, when asked what they think of their country's foreign aid strategy, they do not prioritize spending scarce money on others. Although it could be argued that the trade-off included in the treatment is too strong. In a sense that a choice between hospitals in Brazil and foreign aid would push the results against foreign aid support. And, in real politics, this trade-off is not concrete or automatic. This methodological approach emphasizes the importance of public debates and framing effects in designing public policies.

\footnotetext{
${ }^{23}$ Although the results for Brazil's image and its relevance were significant, we do not discuss them in the next section. These two questions occurred prior to the treatments and discussing their answers is beyond the scope of this article.
} 
Additionally, support for foreign aid is not homogeneous across Brazilian society. First, young Brazilians and leftists tend to support foreign aid initiatives more, a finding that can be explained by the fact that as a person grows older, he/she becomes less altruistic (PAXTON and KNACK, 2012). Second, people living in the most developed region of the country (South) were the least supportive of foreign aid. Following an individual-level analysis, we would expect exactly the opposite, as those with higher incomes have the flexibility to take risks and are more likely to have trusting and altruistic behaviors of all types (PAXTON and KNACK, 2012). Nevertheless, this was not the case, which makes us conclude that there are contextual effects at the regional level that affect perceptions toward foreign aid. In the Brazilian case, we believe this feature can be explained by the fact that during recent elections, the prevailing discourse has suggested that the South and Southeast regions are 'carrying' less-developed regions ${ }^{24}$. This perception may make residents of these regions feel less supportive of aid in general, including foreign aid. Third, the results show that Workers' Party voters tend to have a supportive attitude regarding foreign aid, indicating that the former government was conducting a policy that pleased its electorate.

Regarding how the participants reacted to different ways of framing the issue, when the respondents were given information on how much money Brazil spent on Haiti between 2004 and 2014, support for foreign aid increased. This finding is contrary to what we expected, and we offer two alternative explanations for it. First, foreign aid is an abstract concept, and by providing a concrete example through the Haitian case, it is possible that we too were not properly addressing the desirability bias problem. Additionally, the topic of MINUSTAH has been repeatedly highlighted in the media (MESQUITA and MEDEIROS, 2016), and Brazil has received more than 96 thousand Haitian migrants since 2010, which might have increased public awareness of and sensitivity to this issue. Ultimately, when stimulated with this type of framing, people put a face to foreign aid recipients, making it more difficult to claim that the country should cut foreign aid

\footnotetext{
${ }^{24}$ For example, see TV Brasil 247 (2014). Available at <http://www.brasil247.com/pt/247/brasil/159859/IBGEexplica-raiva-de-Sul-e-Sudeste-contra-o-Nordeste.htm>.
} 
due to moral constraints. Second, even if people may know how much money Brazil spends on a specific foreign aid policy, it is possible that the average citizen does not have a clear notion of the precise meaning of that figure. This possibility is relevant to our analysis of how the second treatment affected public opinion.

Although information on how much money Brazil has spent on Haiti during the last decade increased the likelihood that the respondents would support foreign aid, when these figures were contrasted with how those funds could have been used in the Brazilian domestic realm, the effect drastically reversed. This strong trade-off effect when presenting the same information in a relative way could be explained in two ways. First, as anticipated, it is possible that people only understand large figures when they are presented in a familiar frame of reference (TVERSKY and KAHNEMAN, 1981). Thus, while the sum of R 1.3 billion may seem abstract, explaining that Brazil could have built 43 hospitals with this amount may have clarified the concrete cost of helping others. Second, Brazil is still a developing country, and, as other authors have noted, it is difficult to convince local audiences that the country should invest money abroad when it still faces severe domestic problems (MALAMUD, 2011). In particular, considering the current economic and political crisis, it is reasonable to assume that Brazilians would prefer to cut funding for foreign aid when domestic social programs are threatened.

This work sheds light on the complexity of Brazilian public understanding of foreign policy issues, showing that Brazilian do have a fairly good understanding of foreign policy issues. Especially because this study shows that once framing effects are put in place, it affects how Brazilians perceive the issue at stake. The results indicate that Brazilians tend to oppose international activities involving perceived high costs for Brazil. In this sense, foreign aid represents an important piece of the growing evidence to this finding in the emerging literature on Brazilian public opinion and foreign policy (GUIMARÃES, FERNANDES and MALDONADO, 2019; ONUKI et al., 2016; URDINEZ and RODRIGUES, 2017)

\section{Conclusions}

Over the last decade, Brazil has pursued an ambitious foreign policy with the goal of finally reaching the historically coveted status of a global power. To 
achieve this objective, the country increased its number of embassies, pursued an assertive diplomatic strategy in multilateral organizations, and expanded its cooperation initiatives to ultimately become a foreign aid donor. However, now that the country is enduring a severe economic and political crisis, the feasibility of this assertive foreign policy is being questioned (CERVO and LESSA, 2014; MALAMUD, 2017).

At this turning point in Brazilian foreign policy, we aimed to examine Brazilian domestic politics surrounding foreign aid and analyze whether Brazilian citizens support Brazilian Cooperation for International Development. Our results suggest that most Brazilians support the idea of reducing or completely eliminating spending on foreign aid, an attitude that is reinforced when people are given information on how these funds could be spent in the domestic realm. Then, given these findings, we draw three major conclusions.

First, our article poses some concerns in the Brazilian case. In contrast to the PT governments, which followed an assertive foreign policy, the provisional administration seems to be pursuing a less ambitious strategy. Over the last year, the Ministry of Foreign Affairs closed its Hunger Relief Department and commissioned a study to analyze the consequences of closing embassies in Africa and Central America ${ }^{25}$. Similarly, the Ministry of Planning has delayed payments to more than 120 international organizations and is evaluating the possibility of abandoning 34 of them ${ }^{26}$. Then, as the current administration decides whether to follow a less ambitious foreign policy and reduce its investments in foreign aid, it seems probable that Brazilians will support this type of measure. Not only does the average citizen believe that the country should reduce or completely eliminate its foreign aid expenditure, but when given information on how that money could be invested in their own country, the support for cuts increased by almost nine percent, such that four out of five Brazilians supported reducing foreign aid.

\footnotetext{
25For more information, see Folha de São Paulo (2016). Available at <http://www1.folha.uol.com.br/mundo/2016/05/1771982-serra-pede-estudo-de-custo-deembaixadas-na-africa-e-no-caribe.shtml>.

26For more information, see IG (2016a, 2016b). Available at <http://ultimosegundo.ig.com.br/politica/2016-06-16/brasil-estuda-deixar-34-organizacoesinternacionais-para-reduzir-custos.html> and <http://economia.ig.com.br/2016-04-15/brasildeve-r-32-bilhoes-a-120-orgaos-internacionais-como-onu-e-oms.html>.
} 
Moreover, our findings suggest that subgroups of the Brazilian population, such as older people and those living in the South, tend to have a more negative view of foreign aid. These results could be exploited by candidates able to address the concerns of these specific groups.

Second, our article provides insight into emerging countries' cooperation initiatives. Although each case has its own particularities, Brazil is one of a group of developing countries that have expanded their foreign aid policies in recent years (RENZIO and SEIFERT, 2014). One commonality among these nations is the fact that they strengthened their foreign aid policies as their economies were growing and it was projected that their progress toward development would not suffer major setbacks. However, this situation has radically changed for many countries in the last few years. Given the European crisis and the Chinese economic slowdown, most of these developing countries are now going through economic crises that necessarily impact their ability to pursue an active foreign aid policy. Hence, our results can be extrapolated to other developing countries, especially those democracies in which public opinion constrains foreign policy formulation.

Finally, from a more general perspective, our results are relevant to scholars who are interested in how foreign issues can be used by politicians to gain advantage at the national level. It is common for opposition candidates to use foreign policy topics to criticize incumbent candidates. For example, British politicians who supported 'Brexit' successfully framed the money paid to the European Union by contrasting how that funding could be used in the public health service $^{27}$. Our findings suggest that, if skillfully deployed, criticisms regarding the amount of money spent on foreign aid can be utilized to gain votes from a significant portion of the electorate. In another sense, understanding the determinants of support for foreign aid can help the policy makers conceive better arguments in favor of aid, and help them design policies more consistent with public preferences.

Revised by Fraser Robinson

Submitted on June 09, 2018

Accepted on August 05, 2019

\footnotetext{
${ }^{27}$ For more information, see BBC (2016). Available at <http://www.bbc.com/news/uk-politics-eureferendum-36450749>.
} 


\section{References}

ALDRICH, John H.; GELPI, Christopher; FEAVER, Peter; REIFLER, Jason, and SHARP, Kristin Thompson (2006), Foreign policy and the electoral connection. Annual Review of Political Science. Vol. 09, № 01, pp. 477-502.

ALDRICH, John H.; SULLIVAN, John L., and BORGIDA, Eugene (1989), Foreign affairs and issue voting: do presidential candidates 'Waltz before a blind audience?'. American Political Science Review. Vol. 83, № 01, pp. 123-141.

ALMEIDA, Maria Hermínia Tavares de; ONUKI, Janina; CARNEIRO, Leandro Piquet; GUIMARÃES, Feliciano de Sá, and FERNANDES, Ivan Filipe Lopes (2017), 0 Brasil, as Américas e o mundo segundo a opinião do público e dos líderes 2010/2011 - 2014/2016. Relatório de Pesquisa. IRI-USP/CEBRAP.

ALMEIDA, Maria Hermínia Tavares de; ONUKI, Janina, and CARNEIRO, Leandro Piquet (2014), Brasil, as Américas e o mundo: opinião pública e política externa 2010-2011. São Paulo: IRI-USP. Relatório de pesquisa. Available at $<$ ttp://www.usp.br/iri/documentos/brasil_americas_mundo.pdf>. Accessed on December, 16, 2017.

ALMEIDA, Maria Hermínia Tavares de; FERNANDES, Ivan Filipe Lopes, and GUIMARÃES, Feliciano de Sá (2019), Structuring the public opinion on foreign policy issues: the case of Brazil. Working in Progress. ISA. Annual Convention. Toronto.

APOLINÁRIO JÚNIOR, Laerte (2016), Foreign aid and the governance of international financial organizations: the Brazilian-bloc case in the IMF and the World Bank. Brazilian Political Science Review. Vol. 10, № 03, pp. 02-29.

AZEVEDO, Sérgio de; SANTOS JÚNIOR, Orlando Alves, and RIBEIRO, Luiz César de Queiroz (2009), Metrópoles, cultura política e cidadania no Brasil. Cadernos Metrópole. Vol. 11, № 22, pp. 347-366.

BAKER, Andy (2015), Race, paternalism, and foreign aid: evidence from U.S. public opinion. American Political Science Review. Vol. 109, № 01, pp. 93-109.

BBC (2016), EU vote: Brexit to 'free up' NHS Cash. Available at $<$ https://www.bbc.com/news/av/uk-politics-eu-referendum-36054624/eureferendum-brexit-to-free-up-cash-for-nhs>. Accessed on December, 16, 2017.

BECHTEL, Michael M.; HAINMUELLER, Jens, and MARGALIT, Yotam (2014), Preferences for international redistribution: the divide over the Eurozone bailouts. American Journal of Political Science. Vol. 58, № 04, pp. 835-856.

BESHARATI, Neissan and ESTEVES, Paulo (2015), Os BRICS, a cooperação sul-sul e o campo da cooperação para o desenvolvimento internacional. Contexto Internacional. Vol. 37, № 01, pp. 289-330. 
BNDES (2018), Perguntas e respostas sobre nosso apoio à exportação. Available at $<$ chttp://www.bndes.gov.br/wps/portal/site/home/transparencia/consultaoperacoes-bndes/perguntas-respostas/perguntas-respostas-sobre-apoio-aexportacao $>$. Accessed on December, 16, 2018.

BURSTEIN, Paul (2003), The impact of public opinion on public policy: a review and an agenda. Political Research Quarterly. Vol. 56, № 01, pp. 29-40.

CALLEGARO, Mario (2010), Do you know which device your respondent has used to take your online survey. Survey Practice. Vol. 03, № 06, pp. 01-12.

CAMPBELL, James E. (2004), The presidential election of 2004: the fundamentals and the campaign. The Forum. Vol. 02, № 04, pp. 01-16.

CERVO, Amado Luiz (2010), Brazil's rise on the international scene: Brazil and the world. Revista Brasileira de Política Internacional. Vol. 53, № esp., pp. 07-32.

CERVO, Amado Luiz (1994), Socializando o desenvolvimento: uma história da cooperação técnica internacional do Brasil. Revista Brasileira de Política Internacional. Vol. 37, № 01, pp. 37-63.

CERVO, Amado Luiz and LESSA, Antônio Carlos (2014), 0 declínio: inserção internacional do Brasil (2011-2014). Revista Brasileira de Política Internacional. Vol. 57, № 02, pp. 133-151.

CHONG, Alberto and GRADSTEIN, Mark (2008a), What determines foreign aid? The donors' perspective. Journal of Development Economics. Vol. 87, № 01, pp. 0113.

CHONG, Dennis and DRUCKMAN, James N. (2007), Framing public opinion in competitive democracies. American Political Science Review. Vol. 101, № 04, pp. 637-655.

CHRISTENSEN, Steen Fryba (2013), Brazil's foreign policy priorities. Third World Quarterly. Vol. 34, № 02, pp. 271-286.

COLLIER, Paul (2007), The bottom billion: why the poorest countries are failing and what can be done about It. New York: Oxford University Press. 224 pp..

DAUVERGNE, Peter and FARIAS, Déborah B. L. (2012), The rise of Brazil as a global development power. Third World Quarterly. Vol. 33, № 05, pp. 903-917.

EUROPEAN COMMISSION (2019), Eurobarometer special surveys. Available at <https://ec.europa.eu/commfrontoffice/publicopinion/archives/eb_special_439_ 420_en.htm>. Accessed on December, 10, 2017.

FARIA, Carlos Aurélio Pimenta de and PARADIS, Clarisse Goulart (2013), Humanism and solidarity in Brazilian foreign policy under Lula (2003-2010): theory and practice. Brazilian Political Science Review. Vol. 07, № 02, pp. 0836. 
FELIU, Pedro and MIRANDA, Rosana (2011), Congresso Nacional e política externa. O caso do envio de tropas ao Haiti: Argentina, Brasil e Chile. Revista Política Hoje. Vol. 20, № 01, pp. 310-342.

FISHER, Robert J. and KATZ, James E. (2000), Social-desirability bias and the validity of self-reported values. Psychology \& Marketing. Vol. 17, № 02, pp. 105-120.

FOLHA DE SÃO PAULO (2016), Serra pede estudo de custo de embaixadas na África e no Caribe. Available at <http://www1.folha.uol.com.br/mundo/2016/05/1771982-serrapede-estudo-de-custo-de-embaixadas-na-africa-e-no-caribe-shtml>. Accessed on December, 16, 2017.

GUIMARÃES, Feliciano de Sá; FERNANDES, Ivan Filipe, and MALDONADO, Gerardo (2019), Domestic attitudes toward regional leadership: a survey experiment in Brazil. Foreign Policy Analysis. Vol. 16, № 01, pp. 98-117.

HARDT, Matheus Soldi; MOURON, Fernando and APOLINÁRIO JÚNIOR, Laerte (2017), Rising donors in a transitional world: challenges and opportunities for Brazilian technical cooperation. Brazil: Geopolitical Challenges in a Multipolar World. Vol. 02, № 02, pp. 55-80.

HEINRICH, Tobias; KOBAYASHI, Yoshiharu, and BRYANT, Kristin A. (2016), Public opinion and foreign aid cuts in economic crises. World Development. Vol. 77, pp. 66-79.

HIRST, Monica (2011), Brazil's renewed responsibilities in cooperation for development and international security'. In: Engagement on development and security: new actors, new debates. Edited by SHERMAN. Jake; GLEASON, Megan M.; SHIDU, W. P. S., and JONES, Bruce. New York: Center on International Cooperation. pp. 31-40.

HIRST, Monica; LIMA, Regina Soares de, and PINHEIRO, Leticia (2010), A política externa brasileira em tempos de novos horizontes e desafios. Revista Nueva Sociedad. December Special Edition, pp. 22-41.

HOLBROOK, Allyson L.; GREEN, Melanie C., and KROSNICK, Jon A. (2003), Telephone versus face-to-face interviewing of national probability samples with long questionnaires: comparisons of respondent satisficing and social desirability response bias. Public Opinion Quarterly. Vol. 67, № 01, pp. 79-125.

HOLSTI, Ole R. (1992), Public opinion and foreign policy: challenges to the Almond-Lippmann consensus. International Studies Quarterly. Vol. 36, № 04, pp. 439-466.

HURST, Reuben; TIDWELL, Taylor, and HAWKINS, Darren (2017), Down the rathole? Public support for US foreign aid. International Studies Quarterly. Vol. 61, № 02 , pp. 442-454. 
IG (2016a), Brasil deve R\$ 3,2 bilhões a 120 órgãos internacionais, como ONU e OMS. Available at <https://economia.ig.com.br/2016-04-15/brasil-deve-r-32bilhoes-a-120-orgaos-internacionais-como-onu-e-oms.html>. Acessed on December, 16, 2017.

IG (2016b), Brasil estuda deixar 34 organizações internacionais para reduzir custos. Available at <https://ultimosegundo.ig.com.br/politica/2016-0616/brasil-estuda-deixar-34-organizacoes-internacionais-para-reduzircustos.html>. Acessed on December, 16, 2017.

INOUE, Cristina Yumie Aoki and VAZ, Alcides Costa (2012), Brazil as 'Southern donor': beyond hierarchy and national interests in development cooperation? Cambridge Review of International Affairs. Vol. 25, № 04, pp. 507-534.

IPEA/ABC (2016), Cooperação brasileira para o desenvolvimento internacional: 2011-2013. Brasília: Instituto de Pesquisa Econômica Aplicada/Agência Brasileira de Cooperação. 184 pp..

IYENGAR, Shanto; PETERS, Mark D., and KINDER, Donald R. (1982), Experimental demonstrations of the 'not-so-minimal' consequences of television news programs. American Political Science Review. Vol. 76, № 04, pp. 848-858.

JORNAL DO BRASIL (2014), Candidatos a Presidente da República participam de primeiro debate $\mathrm{Na}$ TV. Available at <https://www.huffpostbrasil.com/2014/08/26/presidenciaveis-participam-narede-bandeirantes-do-1-debate-des_a_21676776/>. Accessed on December, 16, 2017.

KRIESI, Hanspeter (2007), The role of European integration in national election campaigns. European Union Politics. Vol. 08, № 01, pp. 83-108.

KRUMPAL, Ivar (2013), Determinants of social desirability bias in sensitive surveys: a literature review. Quality \& Quantity: International Journal of Methodology. Vol. 47, № 04, pp. 2025-2047.

LANCASTER, Carol (2007), Foreign aid: diplomacy, development, domestic politics. Chicago: University of Chicago Press. 288 pp..

LEITE, Iara Costa (2012), Cooperação sul-sul: conceito, história e marcos interpretativos. Observador on-line. Vol. 07, № 03, pp. 01-41.

LEITE, Iara Costa; SUYAMA, Bianca; WAISBICH, Laura Trajber; POMEROY, Melissa; CONSTANTINE, Jennifer; NAVAS-ALEMÁN, Lizbeth; SHANKLAND, Alex and YOUNIS, Musab (2014), Brazil's engagement in international development cooperation: the state of the debate. Londres: IDS. 89 pp..

LOPES, Dawisson Belém (2011), A política externa brasileira e a 'circunstância democrática': do silêncio respeitoso à politização ruidosa. Revista Brasileira de Política Internacional. Vol. 54, № 01, pp. 67-86.

LUMSDAINE, David Halloran (1993), Moral vision in international politics: the foreign Aid regime, 1949-1989. Princeton University Press. 376 pp.. 
MALAMUD, Andrés (2017), Foreign policy retreat: domestic and systemic causes of Brazil's international rollback. Rising Powers Quarterly. Vol. 02, № 02, pp. 149168.

MALAMUD, Andrés (2011), A leader without followers? The growing divergence between the regional and global performance of Brazilian foreign policy. Latin American Politics and Society. Vol. 53, № 03, pp. 01-24.

MAWDSLEY, Emma (2012), The changing geographies of foreign aid and development cooperation: contributions from gift theory. Transactions of the Institute of British Geographers. Vol. 37, № 02, pp. 256-72.

MENDONÇA JÚNIOR, Wilson and FARIA, Carlos Aurélio Pimenta de (2015), A cooperação técnica do Brasil com a África: comparando os governos Fernando Henrique Cardoso (1995-2002) e Lula da Silva (2003-2010). Revista Brasileira de Política Internacional. Vol. 58, № 01, pp. 05-22.

MESQUITA, Rafael and MEDEIROS, Marcelo de Almeida (2016), Legitimising emerging power diplomacy: an analysis of government and media discourses on Brazilian foreign policy under Lula. Contexto Internacional. Vol. 38, № 01, pp. 385-432.

MILANI, Carlos R. S. (2018), Solidariedade e interesse: motivações e estratégias na cooperação internacional para o desenvolvimento. Curitiba: Appris Editora. $350 \mathrm{pp}$.

MILANI, Carlos R. S. and CARVALHO, Tassia C. O. (2013), Cooperação sul-sul e política externa: Brasil e China no continente africano. Estudos Internacionais: Revista de Relações Internacionais. Vol. 01, № 01, pp. 11-35.

MILNER, Helen V. and TINGLEY, Dustin H. (2013), Public opinion and foreign aid: a review essay. International Interactions. Vol. 39, № 03, pp. 389-401.

MILNER, Helen V. and TINGLEY, Dustin H. (2010), The political economy of U.S. foreign aid: American legislators and the domestic politics of aid. Economics \& Politics. Vol. 22, № 02, pp. 200-232.

MOSLEY, Paul (1985), The political economy of foreign aid: a model of the market for a public good. Economic Development and Cultural Change. Vol. 33, № 02, pp. 373-393.

NOEL, Alain and THÉRIEN, Jean-Philippe (2008), Left and right in global politics. Cambridge: Cambridge University Press. 264 pp..

NOEL, Alain and THÉRIEN, Jean-Philippe (2002), Public opinion and global justice. Comparative Political Studies. Vol. 35, № 06, pp. 627-652.

OECD (2019), OECD glossary of statistical terms. Available at $<$ https://stats.oecd.org/glossary/detail.asp?ID=2686>. Accessed on December, $10,2017$. 
OLIVEIRA, Amâncio Jorge Nunes and ONUKI, Janina (2012), South-south cooperation and Brazilian foreign policy. Foreign Policy Research Center Journal. Vol. 03, pp. 80-99.

ONUKI, Janina; ALMEIDA, Maria Hermínia Tavares de, and CARNEIRO, Leandro Piquet (2016), Brazilian foreign policy and the influence of the public opinion. Paper presented at 24th World Congress of Political Science. Istanbul, Turkey.

ONUKI, Janina; MOURON, Fernando, and URDINEZ, Francisco (2016), Latin american perceptions of regional identity and leadership in comparative perspective. Contexto Internacional. Vol. 38, № 01, pp. 433-465.

PAXTON, Pamela and KNACK, Stephen (2012), Individual and country-level factors affecting support for foreign aid. International Political Science Review. Vol. 33, № 02, pp. 171-192.

PEW RESEARCH CENTER (2013), As sequester deadline looms, little support for cutting most programs. Available at <https://www.peoplepress.org/2013/02/22/as-sequester-deadline-looms-little-support-for-cuttingmost-programs/>. Accessed on December, 16, 2017.

PINHEIRO, Leticia and GAIO, Gabrieli (2014), Cooperation for development, Brazilian regional leadership and global protagonism. Brazilian Political Science Review. Vol. 08, № 02, pp. 08-30.

PINO, Bruno Ayllón and LEITE, Iara Costa (2010), La cooperacion Sur-Sur de Brasil: Instrumento de politica exterior y/o manifestacion de solidaridad internacional? Mural Internacional. Vol. 01. № 01, pp. 20-32.

PRESIDÊNCIA DA REPÚBLICA (2003), Pronunciamento do Presidente da República, Luiz Inácio Lula da Silva, na sessão solene de posse no Congresso Nacional. Brasília: Secretaria de Imprensa e Divulgação.

PUENTE, Carlos Alfonso Iglesias (2010), A cooperação técnica horizontal brasileira como instrumento da política externa: a evolução da cooperação técnica com países em desenvolvimento-CTPD-no período 1995-2005. Brasília: Fundação Alexandre de Gusmão. 340 pp..

PUTNAM, Robert D. (1988), Diplomacy and domestic politics: the logic of two-level games. Imternational Organization. Vol. 42, № 03, pp. 427-460.

QUADIR, Fahimul (2013), Rising donors and the new narrative of 'south-south' cooperation: what prospects for changing the landscape of development assistance programmes? Third World Quarterly. Vol. 34, № 02, pp. 321-338.

REDE GLOBO (2018), Em rede social, Bolsonaro critica empréstimos do BNDES para a Venezuela. Available at <https://g1.globo.com/politica/eleicoes/2018/noticia/2018/09/30/em-redesocial-bolsonaro-critica-emprestimos-do-bndes-para-a-venezuela.ghtmls. Acessed on December, 10, 2018. 
REDE GLOBO (2014), Leia e veja íntegra do debate na Globo. Available at <http://g1.globo.com/politica/eleicoes/2014/noticia/2014/10/leia-e-vejaintegra-do-debate-na-globo.html>. Acessed on December, 16, 2017.

RENZIO, Paolo de and SEIFERT, Jurek (2014), South-south cooperation and the future of development assistance: mapping actors and options. Third World Quarterly. Vol. 35, № 10, pp. 1860-1875.

ROSSI, Amanda (2011), Le Monde Diplomatique. Brasil, um país doador. Available at <https://diplomatique.org.br/brasil-um-pais-doador/>. Accessed on December, 16, 2016.

SCHEUFELE, Dietram A. and TEWKSBURY David (2007), French abstract. Journal of Communication. Vol. 57, № 01, pp. 09-20.

SCHIRM, Stefan A. (2012), Leaders in need of followers: emerging powers in global governance. In: Power in the 21st Century: international security and international political economy in a changing world. Edited by FELS, Enrico; KREMER, Jan-Frederik, and KRONENBERG, Katharina. Heidelberg: Springer. pp. 211-236.

SNYDER, Jack; SHAPIRO, Robert Y., and BLOCH-ELKON, Yaeli (2009), Free hand abroad, divide and rule at home. World Politics. Vol. 61, № 01, pp. 155-187.

SOUZA, André de Mello e (2012), A Cooperação para o desenvolvimento Sul-Sul : os casos do Brasil, da Índia e da China. Boletim de Economia e Política Internacional. № 09, pp. 89-99.

STERN, Marc (1998), Development aid: what the public think. Paper. United Nations Development Programme, Office of Development Studies.

TINGLEY, Dustin (2010), Donors and domestic politics: political influences on foreign aid effort. The Quarterly Review of Economics and Finance. Vol. 50, № 01, pp. 40-49.

TV BRASIL 247 (2014), IBGE explica raiva de Sul e Sudeste contra o Nordeste. Available at <https://www.brasil247.com/brasil/ibge-explica-raiva-de-sul-esudeste-contra-o-nordeste>. Accessed on December, 16, 2017.

TVERSKY, Amos and KAHNEMAN, Daniel (1981), The framing of decisions and the psychology of choice. Science. Vol. 211, pp. 453-58.

UNITED NATIONS (2016), Sustainable development goals report 2016. New York: United Nations. 56 pp..

URDINEZ, Francisco and RODRIGUES, Pietro (2017), Trapped in proto-bipolarism? Brazilian perceptions of an emerging Chinese-American rivalry. Rising Powers Quarterly. Vol. 02, № 02, pp. 105-123.

VALENÇA, Marcelo M. and CARVALHO, Gustavo (2014), Soft power, hard aspirations: the shifting role of power in Brazilian foreign policy. Brazilian Political Science Review. Vol. 08, № 03, pp. 66-94. 
VALLER FILHO, Wladimir (2007), O Brasil e a crise haitiana: a cooperação técnica como instrumento de solidariedade e de ação diplomática. Brasília: Thesaurus Editora. 394 pp..

WARNER, Jeroen (2015), South-South cooperation: Brazilian soy diplomacy looking East? Food Security. Vol. 07, № 06, pp. 1175-1185.

WORLD BANK (2018), World development indicators. Available at $<$ https://search.library.wisc.edu/catalog/999829583602121>. Accessed on December, 16, 2018. 


\section{Annexes}

01. Table 03. Descriptive statistics

\begin{tabular}{|c|c|c|c|c|c|c|c|c|c|}
\hline \multirow[b]{2}{*}{ Variable } & \multicolumn{3}{|c|}{ Control } & \multicolumn{3}{|c|}{ Absolute treatment } & \multicolumn{3}{|c|}{ Trade-off treatment } \\
\hline & Mean & SD & $\mathrm{N}$ & Mean & SD & $\mathrm{N}$ & Mean & SD & Obs \\
\hline Foreign aid perception & 0.30 & 0.46 & 702 & 0.38 & 0.49 & 818 & 0.21 & 0.41 & 756 \\
\hline Sex & 0.51 & 0.50 & 702 & 0.51 & 0.50 & 818 & 0.51 & 0.50 & 756 \\
\hline Age & 34.41 & 12.40 & 702 & 34.07 & 12.77 & 818 & 34.30 & 12.64 & 756 \\
\hline Social class & 3.56 & 1.09 & 702 & 3.45 & 1.18 & 818 & 3.48 & 1.14 & 756 \\
\hline Brazil's relevance & 2.98 & 0.72 & 702 & 3.01 & 0.74 & 818 & 3.00 & 0.75 & 756 \\
\hline Brazil's foreign image & 2.59 & 0.97 & 702 & 2.53 & 0.93 & 818 & 2.55 & 0.94 & 756 \\
\hline Information & 3.46 & 1.28 & 702 & 3.55 & 1.28 & 818 & 3.54 & 1.30 & 756 \\
\hline Employed & 0.69 & 0.46 & 702 & 0.67 & 0.47 & 818 & 0.69 & 0.46 & 756 \\
\hline Education & 4.39 & 0.83 & 702 & 4.41 & 0.86 & 818 & 4.46 & 0.91 & 756 \\
\hline PT & 0.27 & 0.44 & 702 & 0.25 & 0.43 & 818 & 0.26 & 0.44 & 756 \\
\hline PSDB & 0.26 & 0.44 & 702 & 0.32 & 0.46 & 818 & 0.26 & 0.44 & 756 \\
\hline Ideology & 2.00 & 0.73 & 702 & 2.02 & 0.73 & 818 & 1.99 & 0.72 & 756 \\
\hline North & 0.08 & 0.27 & 702 & 0.11 & 0.31 & 818 & 0.09 & 0.28 & 756 \\
\hline Northeast & 0.28 & 0.45 & 702 & 0.27 & 0.44 & 818 & 0.28 & 0.45 & 756 \\
\hline Southeast & 0.42 & 0.49 & 702 & 0.38 & 0.48 & 818 & 0.41 & 0.49 & 756 \\
\hline Midwest & 0.08 & 0.27 & 702 & 0.10 & 0.29 & 818 & 0.08 & 0.27 & 756 \\
\hline South & 0.14 & 0.35 & 702 & 0.16 & 0.36 & 818 & 0.15 & 0.35 & 756 \\
\hline
\end{tabular}

Source: Elaborated by the author's.

\section{Socioeconomic and political questions}

clear

set obs 3000

set seed 12345

gen id =_n

generate rand_num $=$ uniform $(0$

egen treat $=$ cut(rand_num), group (2)

03. How much money Brazil spent on MINUSTAH between 2004 and 2014 "Entre 2004 e 2014 o Brasil destinou R\$ 1,3 bilhões em ajuda externa ao Haiti". Between 2004 and 2014, Brazil spent $\mathrm{R} \$ 1.3$ billion on foreign aid in Haiti. 


\section{How that money could have been spent domestically}

"Entre 2004 e 2014 o Brasil destinou R\$ 1,3 bilhões em ajuda externa ao Haiti, dinheiro que poderia ter financiado, no mesmo período, a construção de 43 hospitais no Brasil".

Between 2004 and 2014, Brazil spent $\mathrm{R} \$ 1.3$ billion on foreign aid in Haiti, money that could have financed, during the same period, the construction of 43 hospitals in Brazil.

\section{How they thought Brazil should modify its foreign aid policy}

"De acordo com a sua percepção sobre ajuda externa, o Brasil deveria"

According to your perception of foreign aid, Brazil should:

Aumentar o dinheiro destinado em ajuda externa - Increase spending on foreign aid

Manter o dinheiro destinado em ajuda externa - Maintain spending on foreign aid Diminuir o dinheiro destinado em ajuda externa - Reduce spending on foreign aid Cortar totalmente o dinheiro destinado em ajuda externa - Completely eliminate spending on foreign aid

\section{Questions to control for political variables}

a) Brazilian relevance in the international arena

"Indique, na sua opinião, qual é a relevância que o Brasil tem no cenário internacional"

Indicate, in your opinion, Brazil's relevance in the international arena:

Muito Importante - Very Important

Importante - Important

Pouco Importante - A Little Important

Nada Importante - Not At All Important

b) Opinion on how Brazil is perceived abroad

"Indique, na sua opinião, qual é a visão que se tem do Brasil no exterior"

Indicate, in your opinion, what the image of Brazil abroad is:

Muito positiva - Very Positive

Positiva - Positive

Neutra - Neutral

Negativa - Negative

Muito Negativa - Very Negative

c) Frequency with which the respondent informs him/herself on international issues

"Indique com que frequência você se informa a respeito de assuntos de política internacional. Considere somente o tempo utilizado para se informar em rádios, jornais (eletrônicos ou impressos), revistas, podcasts, programas de televisão e sites de notícias"

Indicate how often you inform yourself about international policy issues. Consider only the time used to obtain information from radio, newspapers (electronic or printed), magazines, podcasts, television shows and websites:

Diariamente - Daily

De quatro a seis vezes por semana - Between four and six times a week

De uma a três vezes por semana - Between one and three times a week

Esporadicamente - Sporadically

Nunca - Never 
d) Party identification

"Abaixo você vê uma lista dos partidos políticos que participaram da última eleição presidencial. Marque qual deles recebeu seu voto no primeiro turno"

Below, you will see a list of the political parties that participated in the last presidential election. Indicate which of them received your vote in the first round: The list included all the political parties that received at least $0.5 \%$ of the votes, together with the options "Other", "I did not vote" and "I do not remember".

e) Political ideology

"Pensando na sua orientação política, onde você se aloca na seguinte escala, na qual 0 significa "politicamente de esquerda" e 10 "politicamente de direita"?"

Thinking about your political orientation, where do you place yourself on the following scale, with 0 meaning "politically left" and 10 "politically right"?

A scale with the options 0 to 10 was presented.

07. Table 04. Cross-tab analysis

\begin{tabular}{llllll}
\hline P4 & & Control & Treatment & Treatment & Total \\
& & & 1 & 2 & \\
\hline Completely & Count & 133 & 131 & 192 & 456 \\
eliminate the & \% within P4 & $29.2 \%$ & $28.7 \%$ & $42.1 \%$ & $100.0 \%$ \\
money destined to & Adjusted Residual & -.9 & -3.6 & 4.5 & \\
foreign aid. & & & & & \\
Reduce the money & Count & 361 & 373 & 405 & 1139 \\
destined to foreign & \% within P4 & $31.7 \%$ & $32.7 \%$ & $35.6 \%$ & $100.0 \%$ \\
aid. & Adjusted Residual & .9 & -3.2 & 2.4 & \\
Maintain the money & Count & 167 & 278 & 138 & 583 \\
destined to foreign & \% within P4 & $28.6 \%$ & $47.7 \%$ & $23.7 \%$ & $100.0 \%$ \\
aid. & Adjusted Residual & -1.3 & 6.9 & -5.7 & \\
Increase the money & Count & 41 & 36 & 21 & 98 \\
destined to foreign & \% within P4 & $41.8 \%$ & $36.7 \%$ & $21.4 \%$ & $100.0 \%$ \\
aid. & Adjusted Residual & 2.4 & .2 & -2.5 & \\
Total & Count & 702 & 818 & 756 & 2276 \\
& \% within P4 & $30.8 \%$ & $35.9 \%$ & $33.2 \%$ & $100.0 \%$ \\
\hline
\end{tabular}

Source: Elaborated by the author's. 
07. Table 05. Chi-square tests

Chi-Square Tests

\begin{tabular}{|l|r|r|r|}
\hline & Value & df & $\begin{array}{c}\text { Asymptotic } \\
\text { Significance } \\
\text { (2-sided) }\end{array}$ \\
\hline Pearson Chi-Square & $70,475^{\mathrm{a}}$ & 6 & .000 \\
Likelihood Ratio & 70.099 & 6 & .000 \\
Linear-by-Linear Association & 20.751 & 1 & .000 \\
N of Valid Cases & 2276 & & \\
\hline
\end{tabular}

a. 0 cells $(0,0 \%)$ have expected count less than 5 . The minimum expected count is 30,23 . 